\title{
Reduction of Recurrent Tendinitis Scar Using Autologous Mesenchymal Stem Cells Derived from Adipose Tissue from the Base of the Tail in Holsteiner Horses (Equus ferus caballus)
}

\author{
Reducción de la Cicatriz de Tendinitis Recidivante Mediante Células Madre Mesenquimales Autólogas \\ Derivadas de Tejido Adiposo de la Base de la Cola en Equinos Holsteiner (Equus ferus caballus)
}

Christopher Rivera $^{1,2}$; Christian Tuemmers ${ }^{3}$; Rodrigo Bañados ${ }^{3}$; Nicolás Vidal-Seguel ${ }^{4,5}$ \& Enrique Montiel-Eulefi ${ }^{1,2}$

RIVERA, C.; TUEMMERS, C.; BAÑADOS, R.; VIDAL-SEGUEL, N. \& MONTIEL-EULEFI, E. Reduction of recurrent tendonitis scar using autologous mesenchymal stem cells derived from adipose tissue from the base of the tail in Holsteiner horses (Equus ferus caballus). Int. J. Morphol., 38(1):186-192, 2020.

SUMMARY: As a result of their intense physical activity, racehorses suffer high tendon stress which may result in various pathologies. One of these is tendonitis in the tendon of the superficial digital flexor muscle (TSDFM). Conventional treatment with rest, has not shown to be very effective, and regenerative medicine through the application mesenchymal stem cells appears to be a promising therapy. The objective of this work was to assess the effect of the application of autologous MSC on reduction of the scar length in recurrent TSDFM tendinitis in Holsteiner horses, using image analysis. This study included two groups of five animals each: A control group that received conventional treatment (CG) and an experimental group which was also treated with intralesional injections of MSC (EG). Scar evolution was assessed by echographic analysis, with measurements taken of the scar length over a four month period; the length at month zero, was taken as the initial value of $100 \%$. During the first month, the mean scar length diminished to $81.14 \%$ (EG) and $95.85 \%$ (CG); after the second month, lengths were $64.4 \%$ (EG) and $92.3 \%$ (CG); following the third month lengths were $51.92 \%$ (EG) and $87.42 \%$ (CG); finally at the end of the fourth month the lengths recorded were $26.7 \%$ (EG) and $83.92 \%$ (CG). These results show that treatment with autologous MSC helps TSDFM scar length was significantly reduced, as compared to conventional treatment.

KEY WORDS: Horse; MSC; Regenerative medicine; TSDFM.

\section{INTRODUCTION}

Horses have hyper-extended joints and long tendons associated with a muscle distribution evolved to reduce weight in the distal portion of the limb, thus producing protraction and more efficient locomotion (Richardson et al., 2007). The tendons of racehorses are subjected to great tension and absorb a large amount of energy, working close to their mechanical limits. This type of work results in an increased rate of injury. The tendons are among the tissues most affected by pathologies associated with overloading (Tyrnenopoulou et al., 2016). The damaged tendon recovers, however its function remains altered, implying a substantial risk of a new injury (Violini et al., 2009; Brandão et al., 2018). The probability of recurrence of tendonitis may be as high as $43 \%$ if the horse returns to racing (Roth et al.,
2017). These lesions are namely repaired by fibrocytes, however lack of regeneration during athletic activity may lead to the accumulation of damage and degenerative changes, increased by age, repeated mechanical stress and the poor tendon vascularisation (Dudhia et al., 2015). Normally, when the tendon is exercised the heat of the tissue increases and the blood flow to it decreases. In vivo studies have shown that the temperature of the centre of the tendon of the superficial digital flexor muscle (TSDFM) increases to around $45^{\circ} \mathrm{C}$ after a 7 -minute gallop, while the surface temperature is only $35^{\circ} \mathrm{C}$. It has been suggested that these thermal effects result in cell death or imperfect metabolism of the tendinocytes, which are the fibroblasts responsible for synthesising the extracellular matrix (ECM), and for

\footnotetext{
${ }^{1}$ Laboratorio de Biomedicina, Departamento de Ciencias Básicas, Facultad de Medicina, Universidad de La Frontera, Temuco, Chile.

${ }^{2}$ Centro de Biotecnología en Reproducción (CEBIOR-BIOREN), Universidad de La Frontera, Temuco, Chile.

${ }^{3}$ Escuela de Medicina Veterinaria, Universidad Católica, Temuco, Chile.

${ }^{4}$ Escuela de Enfermería, Facultad de Salud, Universidad Santo Tomás, Chile.

${ }^{5}$ Becario CONICYT-PCHA/MAGISTER NACIONAL/ 2017-22170070
} 
tissue remodelling and regeneration (Pacini et al., 2007; Alsook et al., 2015). In a tendon injury, rupture of the fibrils provokes an inflammatory response with infiltration of neutrophils, macrophages and monocytes, which release proteolytic enzymes and induce additional damage (Lombana et al., 2015). Subsequent to the inflammatory process, the necrotic tissue is removed by the action of macrophages, which migrate to the area of the lesion. In the scar tissue repair stage, the collagen formed initially is immature, consisting mainly of small diameter fibres (Type III collagen) in a disorganised arrangement. As they mature, the collagen fibres grow thicker establish a more parallel arrangement, similar to Type I collagen, especially if the animal is subjected to controlled exercise (Gillis, 1997). Tendonitis is characterised by damage to the collagen fibres and an increase in the tendon's transverse diameter as a result of the inflammatory process. The presence of scar tissue in the injured tendon results in lower resistance to physical stress than in a normal tendon, increasing the risk of lesion recurrence in horses undergoing physical training (Smith \& Goodship, 2004).

Regenerative medicine appeared as an innovative method which provided a way of breaking the instability barrier in the resolution of soft tissue problems, offering advantages over conventional therapies (Raabe et al., 2013). The cells of the vascular fraction of adipose tissue are one of the main sources for the extraction of mesenchymal stem cells (MSC) (Zuk et al., 2002), which can be injected into the lesion (Reef, 1998). The expected result is tissue regeneration, expressed in a reduction of irregular collagen tissue, alignment of the tendon fibres, and reduction of inflammatory infiltrate and the haemorrhagic zone. This produces tendon repair with a stable cell matrix, providing greater support to this structure and enabling the horse to return to race training (Kol et al., 2013). Stem cells derived from adult tissues can participate in tissue regeneration through different mechanisms: by direct contribution, through phenotype differentiation of specific cells in the tissue, by generating ECM, by increasing the size of blood vessels and by remodelling the scar tissue (Nixon et al., 2008; Conze et al., 2014; Geburek et al., 2017). MSC can be obtained from various sources in adults; they can be extracted from bone marrow, perivascular tissue, blood, tendons, muscle and adipose tissue. All of these can be used as a source of pluripotent autogenous cells for transplant (Montiel-Eulefi et al., 2009, 2011, 2012; Herrera-Bravo et al., 2013; Bavin et al., 2017). However, the MSC derived from bone marrow and adipose tissue present particularly good proliferation and differentiation in fibroblasts, favouring the production of ECM. These sources of stem cells offer an attractive alternative for tissue engineering in tendons and ligaments (Hankemeier et al., 2005).
Autologous forms of MSC present an additional advantage, in that they do not induce an auto-immune response in the host (Bianchi de Di Risio et al., 2004; Brandão et al.). Adipose tissue is derived from embryonic mesenchyme, and in the adult, contains a stroma which can easily be isolated, with little stress for the animal and rapid recovery (Zuk et al., 2001, 2002). In particular, the fat at the base of the tail is the most accessible in horses with firm musculature, and it can be removed surgically after sedation and local anaesthesia (Nixon et al.). The yield of adipose tissue cells may be influenced by the age of the animal and the site of tissue collection (Vidal et al., 2007). Isolation of the nucleated cells fraction from the fat provides a pool of cells for immediate injection or future use (Nixon et al.).

The aim of this study is to assess the effect of intralesional injection of autologous MSC obtained from the adipose tissue at the base of the tail on the reduction of the length of the scar caused by recurrent tendonitis of the TSDFM in Holsteiner horses.

\section{MATERIAL AND METHOD}

This work studied 10 Holsteiner breed horses, diagnosed with recurrent tendinitis of the TSDFM. They were all racehorses and patients of the Veterinary Medicine School of the Universidad Católica de Temuco. The horses were randomly divided into two groups, 5 animals in the conventional treatment group (CG) and 5 in the group treated with intralesional injections of autologous MSC (EG). The horses were kept in stables and underwent daily exercise routines, under the supervision of a veterinarian. Inclusion criteria for the study were racehorses aged over 2 years, in full physical activity, which presented recurrent tendonitis of the TSDFM in the foreleg. Image evaluations were carried out by echography over a 4-month period.

Diagnosis and identification of tendon lesion was carried out by ultrasound echography. Tendonitis was diagnosed by clinical examination and confirmed by echography. The clinical signs in the horse were based on local temperature increase, painful sensitivity to palpation, observation of the tendon in response to forefoot movement and presence of lameness. The latter was classified on a scale of 0 to 5, following the criteria of the American Association of Equine Practitioners (Stashak, 2008; Baxter, 2011), where $0=$ normal and $5=$ inability to place weight on the affected limb. The ultrasound was carried out with a Pie Medical echography model Aquila Vet. The procedure was carried out with the animal standing still, using a transducer with frequency of $7.5 \mathrm{MHz}$ equipped with a silicon pad 
RIVERA, C.; TUEMMERS, C.; BAÑADOS, R.; VIDAL, N. \& MONTIEL-EULEFI, E. Reduction of recurrent tendonitis scar using autologous mesenchymal stem cells derived from adipose tissue from the base of the tail in Holsteiner horses (Equus ferus caballus). Int. J. Morphol., 38(1):186-192, 2020.

(stand-off). Longitudinal and transverse ultrasound sections were carried out, determining the zone of the lesion, the scar length and the scar classification of the tendon core, divided into four grades; Grade I: diffuse loss of fiber density in the tendon; Grade II: presence of an anechoic area covering less than $50 \%$ of the transverse section of the tendon (TST); Grade III: presence of an anechoic area covering more than $50 \%$ of the TST; Grade IV: $90 \%$ or more of the TST affected (tendon rupture) (Marfe et al., 2012). The rehabilitation period was also monitored by echography, with ultrasound images taken to evaluate scar response to therapy.

To surgical extraction of adipose tissue, the horse was sedated by injection of xylazine $10 \%$ in constant infusion, evaluating the effect after each bolus until the desired level was reached. The peri-coccygeal area was shaved, cleaned and disinfected with alcohol-iodide at 1 $\%$. The incision zone was desensitised with a subcutaneous $2 \%$ lidocaine injection, using the ring-block technique. An incision of a 10 centimetre window approximately, and 1 centimetre depth, was performed perpendicular to the base of the tail and two fingers away from the sagittal midline, following the furrow formed by the femoral biceps and semitendinosus muscles. From this incision, 15 to $20 \mathrm{~g}$ of subcutaneous adipose tissue was extracted and placed in a conical $50 \mathrm{ml}$ tube with $30 \mathrm{ml}$ of sterile PBS at $4{ }^{\circ} \mathrm{C}$. Finally the incision was closed with a polypropylene 0 suture, with simple interrupted suture pattern (Nixon et al.; Vidal et al.).

The MSC was obtained from the adipose tissue in a sterile environment. The tissue was separated with a surgical blade, then washed with an equal volume of phosphate buffered saline (PBS) and agitated briefly for separation into 2 phases. The upper phase contained the cut adipose tissue and washing buffer. The inferior phase of a liquid consistency, contained the haematopoietic cells in suspension. This phase was eliminated. The tissue in the upper phase was digested in an equal volume of PBS with $1 \%$ BSA and $0.1 \%$ Type I collagenase, previously filtered $(0.2 \mathrm{~mm})$, continuously agitated for $30-60$ minutes at 37 ${ }^{\circ} \mathrm{C}$ and then centrifuged at $500 \mathrm{~g}$ for 5 minutes (Watts $e t$ al., 2011). The pellet was washed and re-suspended in a solution of ammonium chloride $(\mathrm{NH} 4 \mathrm{Cl})$ at room temperature for 10 minutes, then centrifuged at $600 \mathrm{~g}$ for 5 minutes, resulting in a pellet of the stromal vascular fraction (SVF). This fraction presented nucleated cells, most of which were perivascular MSC (Zuk et al., 2001, 2002). The MSC pellet was re-suspended in sterile PBS solution at a concentration of $1 \times 106$ cells $/ \mathrm{ml}$. Aliquots of $0.6 \mathrm{ml}$ were taken, loaded into 3 sterile syringes labelled with the data and identification of the donor horse and kept at $4{ }^{\circ} \mathrm{C}$ for 24 hours (Watts et al.).
The intralesional injection of MSC was carried out in the metacarpal zone in accordance with the ultrasound image of the lesion, 24 hours after extraction of the adipose tissue. The zone was shaved, washed with antiseptic soap and disinfected with alcohol prior to injection of the MSC. Guided by ultrasound probe from the lateral perspective of the TSDFM, to ensure that the needle entered the centre of the lesion. Each animal treated received an injection of 0.6 $\mathrm{ml}$ of MSC solution with a $22 \mathrm{G}$ needle.

The scar caused by recurrent tendonitis of the TSDFM was measured and analysed by ultrasound. The echogenicity of the tendon and the skin was shown in the upper half of the screen, while the lower half showed the deeper structures with poorer definition (Fig. 1A). The scar length at month 0 was taken as $100 \%$ and progress was assessed through the $\%$-age reduction of the scar. The scar lengths were measured with calliper application, included in the digital analysis system of the ultrasound equipment (Fig. 1B-C), as shown in the diagram (Fig. 1D).

The horses in both CG and EG were included in a standardised exercise routine (Kasashima et al., 2008) designed to help regeneration and maturation of damaged tissue. The exercise protocol consisted of four stages, corresponding to the 4 months of the study. The exercise in the first month consisted of 1 minute walking per day. In the second month it was changed to 30 seconds walking per day followed by 1 minute trotting. The routine in the third month included additionally 5 periods of trotting for 1 minute and finally in the fourth month 3 periods galloping for 15 seconds were added, finishing with 1 minute trotting and 30 seconds standing still (Kasashima et al.).

Statistical non-parametric Mann-Whitney U test was used to establish the differences of the means in the percentage scar lengths between the two groups in each month of treatment. Differences were considered significant at $p<0.05$. The graphics were generated using the GraphPad Prism software version 6.00 for Windows (GraphPad Software, Inc. La Jolla California, USA).

\section{RESULTS}

Physical examination of the horse showed a degree of claudication in walking and circular trotting; head movements and pelvis elevation were observed, consistent with claudication factor 2 (according to the criteria of the American Association of Equine Practitioners). Upon clinical examination it was observed that the injection produced a slight inflammatory reaction which lasted for three days. 

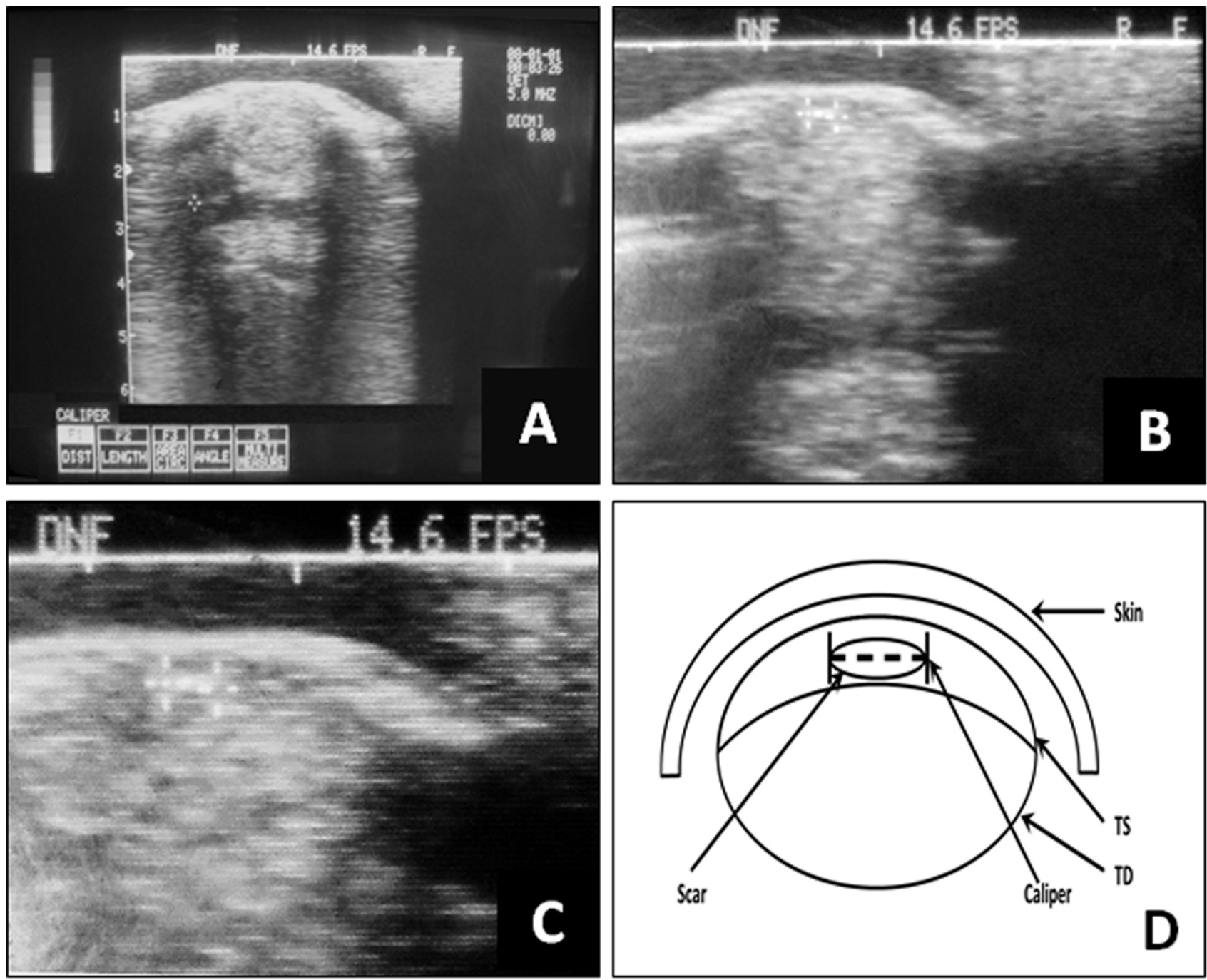

Fig. 1. Ultrasound of the transverse section of the left forefoot of the horse. (A) Amplified ultrasound image showing the tendons of the superficial and deep flexor muscles. (B) Detail of the measurement calliper superimposed on the tendon of the superficial digital flexor muscle. (C) Amplification showing how the scar length in the tendon was measured with the caliper (+--+). (D) Diagram of the ultrasound screen indicating the hyperechogenic regions of tendon of the deep digital flexor muscle (TD) and the scar (elipse) on the tendon of the superficial digital flexor muscle (TS).

This was treated in all patients with cold water for 15 minutes daily, with all signs of inflammation reduced 5 days posttreatment. During the first three weeks, a clinical improvement was detected in the EG, with diminished oedema in the middle third of the metacarpal region and reduced pain under palpation. The horses in the CG continued to present an inflammatory process, with increased oedema, pain under palpation and erythema in the middle third of the metacarpal region. The echogenicity of the lesion became apparent on the day after treatment. At the end of the first month the mean scar length in the EG was $81.14 \%$ and in the CG $95.8 \%$ (p = 0.41 ) (Fig. 2). At the end of the second month the two groups behaved in exactly the same way, with no increase in volumes or abnormal high temperatures in the region of the lesion. No important differences were detected between the two groups during ultrasound examination: a heterogeneous tendinous structure was observed with non-parallel fibres. A small difference was observed in the damaged area, since both groups presented round, core-type, hypoechogenic regions and reduction of the chronic scar, but the scar length was significantly smaller in the EG with a mean of $64.4 \%$ versus $92.3 \%$ in control $(\mathrm{p}=0.03)$ (Fig. 2). At the end of the third month, both groups were examined by ultrasound. The EG showed total resorption of the extravascular fluid in the region of the lesion, some degree of fibrosis and a significantly smaller and reduced hyperechoic scar of $46.08 \%$ as compared to 87.42 $\%$ in the $\mathrm{CG}(\mathrm{p}=0.0079)$ (Fig. 2). In the ultrasound evaluation at the end of the fourth month, the EG presented tendons 
with a good structural pattern, both longitudinal and transverse, with no adhering tissue; the echogenicity was returning to normal with homogeneous appearance and mean scar length of $26.7 \%$, and the mean scar length in the CG was $83.92 \%(\mathrm{p}=0.0079)$, showing extremely significant differences (Fig. 2).

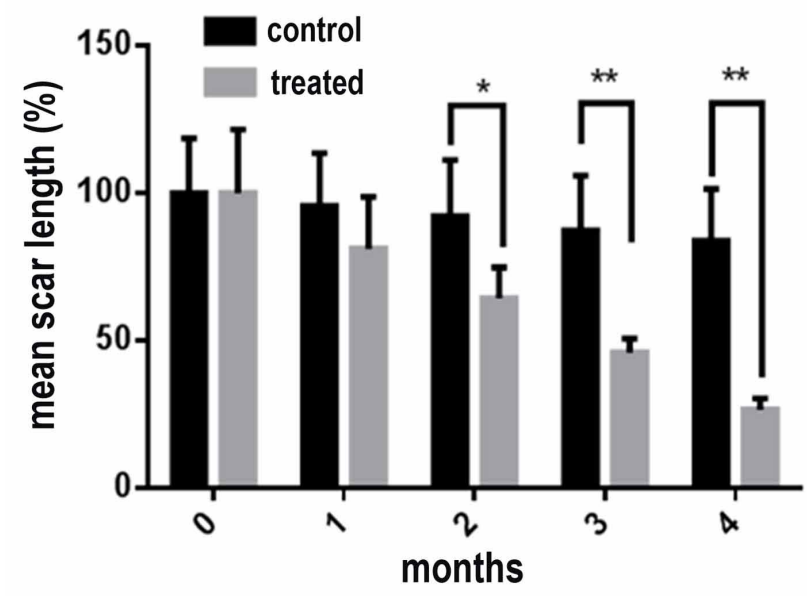

Fig. 2. Scar length reduction in the superficial tendons. The graph shows the monthly mean scar length (percentage) of the injured tendon as compared to month zero $(100 \%)$ in control animals versus those treated with MSC. The scar was significantly shorter in the treated animals in months 2,3 and 4, graph shows the mean $\pm \mathrm{SD} ; *=\mathrm{p}<0.05 ; * *=\mathrm{p}<0.01$.

\section{DISCUSSION}

Ultrasound is an easily accessible technique, safe, non-invasive and an effective way of analysing soft tissue lesions (Denoix, 1994). Ultrasound is considered especially sensitive to determine possible lesions in muscles, tendons, ligaments, joint capsules and cartilages (Pharr \& Nyland, 1984). In the mid-1980s, veterinarians started using this technique for diagnosing lesions in digital flexor tendons and suspensory ligaments (SL) in racehorses (Genovese et al., 1986). This allowed them to diagnose and monitor lesions (Reef, 2001). Ultrasound depends on the echogenicity of the tissues, where the collagen is the largest source of echogenicity in the tendon, since - with other similar proteins - it forms the fibrous stroma of the soft tissues. TSDFM images are obtained in the longitudinal and transverse planes and show difficulties to find a good area of contact between the transducer and the common integument in the transverse plane, due to the convex form of the palmar surface of the metacarpal region in horses (Genovese et al.). The image of normal TSDFM is highly echogenic, with a compact structure formed by correctly oriented collagen bundles and fibres. Hypoechoic lines are sometimes observed inside the tendon; these are endotendinous septs, blood or lymphatic vessels or nerves (Fornage, 1989). In longitudinal section, we find the fibres organised in a linear arrangement, as a large number of parallel echoic lines. This appearance is described as a "fibrillar" echography (Fornage). Combining longitudinal and transverse echographies produces a three-dimensional image of the injured tendon, as well as identifying the location and measurement of the lesion site (Spaulding, 1984; Genovese et al.). Echographic analysis allowed efficient, sensitive comparative analysis to evaluate the TSDFM between the horses in the study, as described in previous works (Denoix; Pharr \& Nyland).

The bone marrow is proposed as a rich, high-potential source of MSC (Bianchi de Di Risio et al.), however the great complexity and high cost of obtaining it in large animals like horses makes access impractical. Adipose tissue is an accessible source with abundant MSC for cell therapy, which also contributes bioactive proteins that encourage tissue regeneration (Taléns-Visconti et al., 2007; Tetta et al., 2012). It can be obtained by methods with low morbility and discomfort for the animal (Zuk et al., 2001, 2002). In this work, adipose tissue was obtained surgically from the base of the tail, an easily accessible part of the horse's anatomy with firm musculature offering great potential for MSC extraction (Nixon et al.; Watts et al.). The adipose tissue digestion protocol used, based on the work of Kern et al. (2006) and Vidal et al., proved to be a very quick, simple process for obtaining MSC. The injection of MSC derived from adipose tissue presented similar results to those reported in other works (Kol et al.; Nixon et al.), with no adverse effects resulting from the injection. (Zuk et al., 2001, 2002). The results obtained were effective in the recovery of normal tendon structure. The principal finding was a good longitudinal and transverse pattern in echography, with no adhering tissue, returning to normal echogenicity with homogeneous appearance four months after treatment. These results are comparable with those reported by Carvalho et al. (2013), who also obtained partial reduction of the acute tendon lesion in two months using the same therapy. Histopathological studies with cell therapy derived from adipose tissue and applied to horses, show that the morphology improves in the injured tendon, with a larger number of collagen fibres with regular distribution and a larger number of blood vessels (Nixon et al.; Geburek et al., 2016). However, this type of analysis is not documented in the present work due to the impossibility of carrying out a biopsy of horse tendons. Nevertheless, the ultrasound image allowed us to observe an improvement in the parallel organisation of the collagen fibres. Subjecting the horse to training with increasing intensity over the weeks helps the maturation of the lesion (Kasashima et al.). The horses treated with autologous stem cell therapy in this work carried 
out all their training activities with no problems and without manifesting pain, easily improving on the $43 \%$ recovery rate for recurrent tendonitis lesions under conventional treatments, as described by Roth et al., In this work all the animals were subjected to the same exercise protocol (Lacitignola et al., 2008), thus the difference in scar length can only be attributed to the MSC. In conclusion, the application of autologous MSC, isolated from the vascular fraction of adipose tissue from the base of the tail, reduces the scar length in recurrent tendinopathies of the TSDFM in Holsteiner horses from the second to the fourth month post intervention.

\section{ACKNOWLEDGEMENTS}

This work was funded by project 2009-3-10 DGIUCT, Universidad Católica de Temuco. N. Vidal was a Master's Scholar, financed by CONICYT (CONICYTPCHA/MAGISTER NACIONAL/ 2017-22170070)

RIVERA, C.; TUEMMERS, C.; BAÑADOS, R.; VIDAL, N. \& MONTIEL-EULEFI, E. Reducción de la cicatriz de tendinitis recidivante mediante células madre mesenquimales autólogas derivadas de tejido adiposo de la base de la cola en equinos Holsteiner (Equus ferus caballus). Int. J. Morphol., 38(1):186-192, 2020.

RESUMEN: Reducción de la cicatriz de tendinitis recidivante mediante células Madre mesenquimales autólogas derivadas de tejido adiposo de la base de la cola en equinos Holsteiner (Equus ferus caballus). En equinos deportistas, la actividad física intensa ocasiona gran estrés en los tendones, pudiendo ocasionar diversas patologías como la tendinitis del tendón del músculo flexor digital superficial (TMFDS). El tratamiento convencional con reposo es poco eficaz, siendo la medicina regenerativa a través de la aplicación de células madres mesenquimáticas (MSC) una promisoria terapia. El objetivo de este trabajo, fue evaluar el efecto de la aplicación de MSC autólogas, sobre la reducción de la longitud de la cicatriz en tendinopatías recidivantes del TMFDS en equinos Holsteiner, a través del análisis de imagen. Este estudio conto con dos grupos de cinco animales cada uno, el grupo control mantuvo el tratamiento convencional (GC) y el grupo experimental fue tratado adicionalmente con inyección interlesional de MSC (GE). El análisis ecográfico permitió evaluar la evolución de la cicatriz, a través de la medición de su longitud durante los cuatros meses, tomando la longitud del mes cero como la medición inicial del $100 \%$. Durante el primer mes, la longitud de la cicatriz se redujo a un $81,14 \%$ (GE) y 95,85 \% (GC), al segundo mes la longitud fue de un $64,4 \%$ (GE) y de $92,3 \%$ (GC), al tercer mes, la longitud fue de 51,92 (GE) y un 87,42 (GC), finalmente al cuarto mes la longitud fue de $26,7 \%$ (GE) y del 83,92 \% (GC). Estos resultados muestran que el tratamiento con MSC autólogas favorece a la disminución de la longitud de la cicatriz del TMFDS de forma significativa respecto al tratamiento convencional.

PALABRAS ClAVE: Equino; TFDS; Medicina regenerativa, MSC.

\section{REFERENCES}

Alsook, M. K. S.; Gabriel, A.; Piret, J.; Waroux, O.; Tonus, C.; Connan, D.; Baise, E. \& Antoine, N. Tissues from equine cadaver ligaments up to 72 hours of post-mortem: a promising reservoir of stem cells. Stem Cell Res. Ther., 6:253, 2015.

Bavin, E. P.; Atkinson, F.; Barsby, T. \& Guest, D. J. Scleraxis is essential for tendon differentiation by equine embryonic stem cells and in equine fetal tenocytes. Stem Cells Dev., 26(6):441-50, 2017.

Baxter, G. M. Adams and Stashak's Lameness in Horses. Oxford, John Wiley \& Sons, 2011.

Bianchi de Di Risio, C. C.; Callero, F.; Hidalgo, A. \& Argibay, P. Células mesenquimales de médula ósea. Diferenciación y potencial reemplazo neuronal. Medicina (Buenos Aires), 64:543-9, 2004.

Brandão, J. S.; Alvarenga, M. L.; Pfeifer, J. P. H.; Dos Santos, V. H.; FonsecaAlves, C. E.; Rodrigues, M.; Laufer-Amorim, R.; Castillo, J. A. L. \& Alves, A. L. G. Allogeneic mesenchymal stem cell transplantation in healthy equine superficial digital flexor tendon: A study of the local inflammatory response. Res. Vet. Sci., 118:423-30, 2018.

Carvalho, A. de M.; Badial, P. R.; Álvarez, L. E.; Yamada, A. L.; Borges, A. S.; Deffune, E.; Hussni, C. A. \& Garcia Alves, A. L. Equine tendonitis therapy using mesenchymal stem cells and platelet concentrates: a randomized controlled trial. Stem Cell Res. Ther., 4(4):85, 2013.

Conze, P.; van Schie, H. T.; van Weeren, R.; Staszyk, C.; Conrad, S.; Skutella, T.; Hopster, K.; Rohn, K.; Stadler, P. \& Geburek, F. Effect of autologous adipose tissue-derived mesenchymal stem cells on neovascularization of artificial equine tendon lesions. Regen. Med., 9(6):743-57, 2014.

Denoix, J. M. Diagnostic techniques for identification and documentation of tendon and ligament injuries. Vet. Clin. North Am. Equine Pract., 10(2):365-407, 1994.

Dudhia, J.; Becerra, P.; Valdés, M. A.; Neves, F.; Hartman, N. G. \& Smith, R. K. In vivo imaging and tracking of Technetium-99m labeled bone marrow mesenchymal stem cells in equine tendinopathy. J. Vis. Exp., (106):e52748, 2015.

Fornage, B. D. Ultrasonography of Muscles and Tendons. Examination Technique and Atlas of Normal Anatomy of the Extremities. Berlin, Springer Science \& Business Media, 1989.

Geburek, F.; Mundle, K.; Conrad, S.; Hellige, M.; Walliser, U.; van Schie, H. T.; van Weeren, R.; Skutella, T. \& Stadler, P. M. Tracking of autologous adipose tissue-derived mesenchymal stromal cells with in vivo magnetic resonance imaging and histology after intralesional treatment of artificial equine tendon lesions--a pilot study. Stem Cell Res. Ther, 7:21, 2016.

Geburek, F.; Roggel, F.; van Schie, H. T. M.; Beineke, A.; Estrada, R.; Weber, K.; Hellige, M.; Rohn, K.; Jagodzinski, M.; Welke, B.; et al. Effect of single intralesional treatment of surgically induced equine superficial digital flexor tendon core lesions with adipose-derived mesenchymal stromal cells: a controlled experimental trial. Stem Cell Res. Ther., 8:129, 2017.

Genovese, R. L.; Rantanen, N. W.; Hauser, M. L. \& Simpson, B. S. Diagnostic ultrasonography of equine limbs. Vet. Clin. North Am. Equine Pract., 2(1):145-226, 1986.

Gillis, C. L. Rehabilitation of tendon and ligament injuries. Am. Assoc. Equine Pract. Proc., 43:306-9, 1997.

Hankemeier, S.; Keus, M.; Zeichen, J.; Jagodzinski, M.; Barkhausen, T.; Bosch, U.; Krettek, C. \& Van Griensven, M. Modulation of proliferation and differentiation of human bone marrow stromal cells by fibroblast growth factor 2: potential implications for tissue engineering of tendons and ligaments. Tissue Eng., 11(1-2):41-9, 2005.

Herrera-Bravo, J.; Montiel-Eulefi, E.; Glaser, T.; Garcés, M.; Leal, P. \& Ulrich, H. A. In vitro translocation cytoplasm/nucleus of embryonic transcription factor OCT-4 in perivascular cells suggests that aorta as a niche of quiescent adult stem cells. Int. J. Morphol., 31(4):1430-8, 2013. 
Kasashima, Y.; Takahashi, T.; Birch, H. L.; Smith, R. K. \& Goodship, A. E. Can exercise modulate the maturation of functionally different immature tendons in the horse? J. Appl. Physiol. (1985), 104(2):416-22, 2008.

Kern, S.; Eichler, H.; Stoeve, J.; Klüter, H. \& Bieback, K. Comparative analysis of mesenchymal stem cells from bone marrow, umbilical cord blood, or adipose tissue. Stem Cells, 24(5):1294-301, 2006.

Kol, A.; Walker, N. J.; Galuppo, L. D.; Clark, K. C.; Buerchler, S.; Bernanke, A. \& Borjesson, D. L. Autologous point-of-care cellular therapies variably induce equine mesenchymal stem cell migration, proliferation and cytokine expression. Equine Vet. J., 45(2):193-8, 2013.

Lacitignola, L.; Crovace, A.; Rossi, G. \& Francioso, E. Cell therapy for tendinitis, experimental and clinical report. Vet. Res. Commun., 32 Suppl. 1:S33-8, 2008.

Lombana, K. G.; Goodrich, L. R.; Phillips, J. N.; Kisiday, J. D.; RupleCzerniak, A. \& McIlwraith, C. W. An investigation of equine mesenchymal stem cell characteristics from different harvest sites: more similar than not. Front. Vet. Sci., 2:67, 2015.

Marfe, G.; Rotta, G.; De Martino, L.; Tafani, M.; Fiorito, F.; Di Stefano, C.; Polettini, M.; Ranalli, M.; Russo, M. A. \& Gambacurta, A. A new clinical approach: use of blood-derived stem cells (BDSCs) for superficial digital flexor tendon injuries in horses. Life Sci., 90(21-22):82530, 2012.

Montiel-Eulefi, E.; Barrientos Díaz, L.; Leal, P.; Roa, J. C.; Risopatrón, J.; Salazar, L. A.; Romero, F. \& Sánchez, R. Pericytes: new approaches in regenerative therapy, cerebrovascular pathology and cancer. Int. J. Morphol., 29(3):769-81, 2011.

Montiel-Eulefi, E.; Nery, A. A.; Rodrigues, L. C.; Sanchez, R.; Romero, F. \& Ulrich, H. Neural differentiation of rat aorta pericyte cells. Cytometry A, 81(1):65-71, 2012.

Montiel-Eulefi, E.; Sánchez, R.; Rojas, M. \& Bustos-Obregón, E. Epiblast embryo stem cells give origin to adult pluripotent cell populations: primordial germ cell, pericytic and haematopoyetic stem cells. A review. Int. J. Morphol., 27(4):1325-1333, 2009.

Nixon, A. J.; Dahlgren, L. A.; Haupt, J. L.; Yeager, A. E. \& Ward, D. L. Effect of adipose-derived nucleated cell fractions on tendon repair in horses with collagenase-induced tendinitis. Am. J. Vet. Res., 69(7):92837, 2008.

Pacini, S.; Spinabella, S.; Trombi, L.; Fazzi, R.; Galimberti, S.; Dini, F.; Carlucci, F. \& Petrini, M. Suspension of bone marrow-derived undifferentiated mesenchymal stromal cells for repair of superficial digital flexor tendon in race horses. Tissue Eng, 13(12):2949-55, 2007.

Pharr, J. W. \& Nyland, T. G. Sonography of the equine palmar metacarpal soft tissues. Vet. Radiol., 25(6):265-73, 1984

Raabe, O.; Shell, K.; Goessl, A.; Crispens, C.; Delhasse, Y.; Eva, A.; Scheiner-Bobis, G.; Wenisch, S. \& Arnhold, S. Effect of extracorporeal shock wave on proliferation and differentiation of equine adipose tissuederived mesenchymal stem cells in vitro. Am. J. Stem Cells, 2(1):6273, 2013.

Reef, V. B. Equine Diagnostic Ultrasound. Philadelphia, W. B. Saunders, 1998.

Reef, V. B. Superficial digital flexor tendon healing: ultrasonographic evaluation of therapies. Vet. Clin. North Am. Equine Pract., 17(1):15978, 2001.

Richardson, L. E.; Dudhia, J.; Clegg, P. D. \& Smith, R. Stem cells in veterinary medicine--attempts at regenerating equine tendon after injury. Trends Biotechnol., 25(9):409-16, 2007.

Roth, S. P.; Glauche, S. M.; Plenge, A.; Erbe, I.; Heller, S. \& Burk, J. Automated freeze-thaw cycles for decellularization of tendon tissue - a pilot study. B. M. C. Biotechnol., 17:13, 2017.

Smith, R. \& Goodship, A. Tendon and Ligament Physiology. Equine Sports Medicine and Surgery: Basic and Clinical Sciences of the Equine Athlete. Philadelphia, Elsevier, 2004. pp.130-51.

Spaulding, K. Ultrasonic anatomy of the tendons and ligaments in the distal metacarpal-metatarsal region of the equine limb. Vet. Radiol., 25(4):15566, 1984.

Stashak, T. S. Adams' Lameness In Horses. Berlin, Verlag, 2008.
Taléns-Visconti, R.; Bonora, A.; Jover, R.; Mirabet, V.; Carbonell, F.; Castell, J. V. \& Gómez-Lechón, M. J. Human mesenchymal stem cells from adipose tissue: Differentiation into hepatic lineage. Toxicol. In Vitro, 21(2):324-9, 2007.

Tetta, C.; Consiglio, A. L.; Bruno, S.; Tetta, E.; Gatti, E.; Dobreva, M.; Cremonesi, F. \& Camussi, G. The role of microvesicles derived from mesenchymal stem cells in tissue regeneration; a dream for tendon repair? Muscles Ligaments Tendons J., 2(3):212-21, 2012.

Tyrnenopoulou, P.; Karayannopoulou, M.; Angelopoulou, S.; Pyrros, A.; Mparous, E.; Koliakos, G. \& Diakakis, N. Successful management of an equine carpal chip fracture by intra-articularly injected adiposederived stromal vascular fraction after arthroscopic removal. Iran. J. Vet. Res., 17(1):59-61, 2016.

Vidal, M. A.; Kilroy, G. E.; Lopez, M. J.; Johnson, J. R.; Moore, R. M. \& Gimble, J. M. Characterization of equine adipose tissue-derived stromal cells: adipogenic and osteogenic capacity and comparison with bone marrow-derived mesenchymal stromal cells. Vet. Surg., 36(7):613-22, 2007.

Violini, S.; Ramelli, P.; Pisani, L. F.; Gorni, C. \& Mariani, P. Horse bone marrow mesenchymal stem cells express embryo stem cell markers and show the ability for tenogenic differentiation by in vitro exposure to BMP-12. B. M. C. Cell Biol., 10:29, 2009.

Watts, A. E.; Yeager, A. E.; Kopyov, O. V. \& Nixon, A. J. Fetal derived embryonic-like stem cells improve healing in a large animal flexor tendonitis model. Stem Cell Res. Ther, 2(1):4, 2011.

Zuk, P. A.; Zhu, M.; Ashjian, P.; De Ugarte, D. A.; Huang, J. I.; Mizuno, H.; Alfonso, Z. C.; Fraser, J. K.; Benhaim, P. \& Hedrick, M. H. Human adipose tissue is a source of multipotent stem cells. Mol. Biol. Cell, 13(12):4279-95, 2002.

Zuk, P. A.; Zhu, M.; Mizuno, H.; Huang, J.; Futrell, J. W.; Katz, A. J.; Benhaim, P.; Lorenz, H. P. \& Hedrick, M. H. Multilineage cells from human adipose tissue: implications for cell-based therapies. Tissue Eng., 7(2):211-28, 2001.

Corresponding author:

E. Montiel-Eulefi

Universidad de La Frontera

Montevideo 0870

Temuco

CHILE

Email: emontiele@gmail.com

Received: 09-07-2019

Accepted: 05-09-2019 